\title{
Applicability of Sunsik with Cultivated Wild Ginseng Powder as a Beauty Food
}

\author{
Sei-Woo Lee ${ }^{1}$, Hyoung-II Choi ${ }^{2}$, Ae-Jung Kim ${ }^{2 *}$, Jung-Soon $\mathrm{Han}^{3 *}$ \\ ${ }^{1}$ Department of Alternative Medicine, Kyonggi University, Seoul, Korea \\ ${ }^{2}$ Department of Nutrition Therapy, Graduate School of Alternative Medicine, Kyonggi University, Seoul, Korea \\ ${ }^{3}$ Institute of Life Science, College of Education, Korea University, Seoul, Korea
}

\begin{abstract}
"Corresponding author: Ae-Jung Kim, Department of Nutrition Therapy, Graduate School of Alternative Medicine, Kyonggi University, 24 Kyonggidae-ro, 9-gil, Seodaemun-gu, Seoul 03746, Korea Tel.: +82 23905044

Fax: +82 23905078

Email: aj5249@naver.com

Jung-Soon Han,

Institute of Life Science, College of Education, Korea University, 145 Anam-ro, Seongbuk-gu, Seoul 02841, Korea

Email: yohwa0620@gmail.com
\end{abstract}

Ae-Jung Kim and Jung-Soon Han contributed equally to this work.

Received August 15, 2017

Revised December 27, 2017

Accepted January 8, 2018

Published June 30, 2018

\begin{abstract}
Purpose: This study was carried out to investigate antioxidant activities of Sunsik supplemented with cultivated wild ginseng powder and its applicability as a beauty food. Methods: After obtaining extracts from cultivated wild ginseng powder and Sunsik using $70 \%$ ethanol, the antioxidant activity of Sunsik supplemented with cultivated wild ginseng powder was measured using the radical scavenging activities of 1,1-diphenyl-2-picrylhydrazyl (DPPH). The contents of calcium, phosphorus, magnesium, potassium, and sodium were also measured by an inductively coupled plasma method. The mean and standard deviation were calculated using SPSS statistics 21. ANOVA was performed for each test group and Duncan's multiple range test was performed at the significance level of $5 \%$. Results: Total polyphenol contents of Sunsik with 0.6\% 15-year cultivated wild ginseng powder (15yrWS0.6) were determined to be the highest one in all the samples, as was the DPPH radical scavenging activity of 15yrWS0.6. Conclusion: Therefore, this study demonstrates that Sunsik possesses antioxidant activity, suggesting that supplemented with cultivated wild ginseng powder can act as an effective functional inner beauty food for health.
\end{abstract}

Keywords: Sunsik, Cultivated wild ginseng, Polyphenol, Antioxidant, Beauty food

\section{Introduction}

현대사회는 경제발전, 생명과학기술의 획기적인 진보, 식생 활 향상과 더불어 평균 수명이 증가되어 고령화 사회로의 진 입이 가속화되고 있으며 건강한 삶에 대한 열망이 증대되고 있 다(Lee et al., 2015). 이를 위한 내적인 건강에 대한 관심, 신 체 외적인 건강과 아름다움에 대한 기대 욕구도 증가하고 있다 (Kim, 2005). 또한 뷰티 산업의 활성화는 건강한 아름다움에 대
한 욕구를 가속화시켜 외면의 아름다움의 바탕이 되는 피부미용 에 대한 관심이 고조되어 있다(Kang et al., 2011). 이러한 피 부 건강에 영향을 미치는 요인에는 피부 관리, 정신, 심리적 요 인, 식생활 습관, 생리적 요인(내분비이상), 외부 환경적 요인(자 외선, 기온변화), 생활 요인(수면부족, 피로) 등이 있다(Jung \& Hwang, 2015). 균형 잡힌 영양섭취는 신체 발육을 양호하게 할 뿐 아니라 정서적 안정 유지와 피부의 일차적 영양 기능에 매우 중요한 역할을 한다(Kim et al., 2014). 이와 같은 시대적 요구 
에 부응하여 최근 미용기능성 식품에 대한 요구가 증가하고 있 으며, 이에 따라 라벤더 향의 스트레스에 대한 연구(Kang et al., 2013), 블루베리 등 추출물의 화장품 소재로서의 효능 연 구(Jang, 2017)와 같은 기능성 식품의 outer beauty 연구와 특 히 인삼을 이용한 피부 관련 식품에 대한 연구도 진행되고 있다 (Yeom et al., 2010). 인삼(Panax ginseng)은 오가피과(두릅 나무과, Araliaceae)에 속하는 다 년생 초본으로 생장 환경에 따 라 산에 야생하는 산삼, 산림에서 직파 또는 이식 재배하는 산양 삼(장뇌삼), 일반 경작지에서 재배하는 재배삼으로 구별하고 있 다(Shin et al., 2001). 야생의 자연환경에서 성장한 산삼과 산 양삼은 재배성장 조건의 인위적 조정 하에 생육한 재배삼보다 methionine, cysteine 및 tryptophan 같은 아미노산 함량이 1.9 배 높아 항우울, 혈압저하, 면역력 강화 등의 활성에서 재배 삼을 앞선다(Kim et al., 2012). 또한 산양삼은 염증매개를 억 제하고 항염증 매개체 생성을 증진시켜 염증으로부터 간을 보호 하며(Kim et al., 2015), 재배삼에서는 발견되지 않는 항암 관 련 ginsenoside Rh2와 칼슘수산화 결정이 함유되어 있다(Choi et al., 2007). 또한 산양삼은 홍삼보다 혈중 지질을 개선시키고 혈당을 감소시켰으며(Yun et al., 2004), 암세포의 apoptosis 에 영향을 미치는 인자들인 nitric oxide (NO) 생성, tumor necrosis factor alpha (TNF $)$ 활성이 산삼, 산양삼, 인삼 순으 로 높아 항암 효과도 큰 것으로 나타났다(Kim et al., 2004). 인 삼류의 면역 증강 효과를 비교한 연구에서도(Kwon \& Chung, 2004) interferon gamma (IFNY) 발현은 산삼, 산양삼, 재배삼 이 모두 증가되었으며, interleukin 12 (IL12) 생성에서는 산양 삼이 높고, interleukin 4 (IL4) 생성에서는 산삼이 높게 나타나 는 등 각기 다른 면역 조절효과를 보여 주고 있다. 그러나 산양 삼이 미용기능성 식품으로서 연구된 바 없다. 한편 선식은 곡류, 채소 등의 식품 원료를 자연 건조하거나 $60^{\circ} \mathrm{C}$ 이하의 송풍 건조
또는 동결 건조 후 분말화한 생식과는 달리 선식을 구성하는 식 품들을 열풍 건조 및 자연 건조 등으로 가공 처리한 제품으로 음 용 편리성과 미생물 위해 정도가 생식보다 낮아 위생적으로 안 전하다(Chung \& Han, 2003). 선식은 구성 식품의 종류 및 비 율 변화에 따라 열량은 낮고 각종 아미노산, 지방산, 무기질, 비 타민 등의 영양소들을 다양하고 풍부하게 제공할 수 있는 영양 밀도가 우수한 가공 식품으로(Kim et al., 2005) 영양적, 기능 적, 관능적 특성을 달리 할 수 있는 다양성이 있다(Lee et al., 2010). 현대인들은 건강한 아름다움에는 관심이 많으나 바쁜 생 활로 식사를 불규칙하게 하거나 거르는 경우가 많아 영양 불균 형을 초래할 수 있으며 이는 피부건강에 긍정적이지 않다. 선식 은 쉽게 구입할 수 있고 조리과정을 최소화할 수 있는 편리성이 있으며 식물성 위주의 각종 영양소를 골고루 함유하고 있는 식 품이다.

이에 본 연구에서는 산양삼을 첨가한 선식을 제조하여 일반 성분과 항산화 활성을 측정하여 미용기능성 식품으로서의 가능 성을 알아보고자 하였다.

\section{Methods}

\section{1. 연구재료}

본 실험에 사용된 산양삼은 (주)지더블유씨(Korea)에서 구입 하였다. 산양삼 첨가 선식에 들어가는 곡물류인 귀리, 현미, 찹 쌀, 쌀보리, 발아보리, 대두, 흑태, 잎채류인 시금치, 양배추, 부 추, 브로콜리, 근채류인 산약마, 천마, 우엉, 야콘, 연근, 더덕, 도라지, 견과류인 아몬드, 코코넛, 기타 단호박, 다시마, 표고버 섯 등의 부재료는 (주한국뉴팜 퍼플네이처(Korea)에서 구입하여 사용하였다.

Table 1. The ingredients of Sunsik prepared with 10 - and 15-year-old cultivated wild ginseng powder

\begin{tabular}{llccc}
\hline Groups $^{1)}$ & Sunsik & 10yrWGP & Water \\
Control & 40 & 0 & 15 yrWGP $^{3)}$ & 160 \\
10yrWS0.2 & 39.8 & 0.2 & 0 & 160 \\
10yrWS0.4 & 39.6 & 0.4 & 0 & 160 \\
10yrWS0.6 & 39.4 & 0.6 & 0 & 160 \\
15yrWS0.2 & 39.8 & 0 & 0.2 & 160 \\
15yrWS0.4 & 39.6 & 0 & 0.4 & 160 \\
15yrWS0.6 & 39.4 & 0 & 0.6 & 160 \\
\hline
\end{tabular}

${ }^{11}$ Control, basic Sunsik consisting of several grains, but not including cultivated wild ginseng powder; 10yrWS0.2, sample with 0.2\% 10yrWGP added to basic Sunsik; 10yrWS0.4, sample with 0.4\% 10yrWGP added to basic Sunsik; 10yrWS0.6, sample with 0.6\% 10yrWGP added to basic Sunsik; 15yrWS0.2, sample with 0.2\% 15yrWGP added to basic Sunsik; 15yrWS0.4, sample with 0.4\% 15yrWGP added to basic Sunsik; 15yrWS0.6, sample with 0.6\% 15yrWGP added to basic Sunsik.

${ }^{2)}$ 10yrWGP, 10-year-old cultivated wild ginseng powder.

3) 15yrWGP, 15-year-old cultivated wild ginseng powder. 


\section{2. 추출물 제조}

산양삼 분말 추출 시료는 산양삼 분말 무게 대비 20 배 부피 의 $70 \%$ ethanol (EtOH; Sigma-Aldrich, USA)을 첨가한 후 $72 \mathrm{~h}$ 동안 상온에서 추출시켜 여과지(Whatman filter paper No.3; GE Healthcare, USA)를 사용하여 여과하여 얻었다. 이렇게 얻은 추출액은 농축기(Rotary Evaporator, EYELA N-1110; Tokyo Rikakikai, Japan)로 용매를 증발시킨 후 동 결건조기(FD5808; IlShinBioBase, Korea)로 동결 건조하여 분 말화 한 후 냉동보관하여 사용하였다.

\section{3. 산양삼 분말을 첨가한 선식 제조}

산양삼은 $65^{\circ} \mathrm{C}$ 에서 $8 \mathrm{~h}$ 건조 후 분쇄하여 40 mesh (Hahnshin S\&T, Korea) 체에 내려 분말화 하였다. 기본 선식 즉 대조군에 10 년산 산양삼 분말 및 15 년산 산양삼 분말을 첨가하여 Table 1 과 같이 시료를 제조하였다.

\section{Total polyphenol 함량}

10 년산, 15 년산 산양삼 분말 첨가량 $(0 \%, 0.2 \%, 0.4 \%$ 및 $0.6 \%)$ 을 달리하여 제조한 산양삼 분말 첨가 선식의 총 폴리페 놀 함량은 Folin-Denis의 방법(Folin \& Denis, 1912)을 변형 하여 측정하였다. $1,000 \mu \mathrm{g} / \mathrm{mL}$ 농도의 산양삼 분말 첨가 선 식 추출물 희석액 $1 \mathrm{~mL}$ 를 취하여 sodium carbonate $\left(\mathrm{Na}_{2} \mathrm{CO}_{3}\right.$; Sigma-Aldrich) 용액 $1 \mathrm{~mL}$ 를 가한 후 $3 \mathrm{~min}$ 간 정치한 후, $50 \%$ Folin-Ciocalteu 시약(Sigma-Aldrich) $0.2 \mathrm{~mL}$ 를 가하여 반응시켜 microplate reader (BN 02514; Molecular Devices, $\mathrm{USA}$ )를 이용하여 $750 \mathrm{~nm}$ 에서 흡광도를 측정하였다. 총 폴리페 놀 함량은 tannic acid (Sigma-Aldrich)를 이용하여 작성한 표 준곡선을 바탕으로 환산하여 나타내었다.

\section{DPPH radical 소거능}

10 년산, 15 년산 산양삼 분말 첨가량 $(0 \%, 0.2 \%, 0.4 \%$ 및 $0.6 \%)$ 을 달리하여 제조한 산양삼 첨가 선식 에탄올 추출물 시료 의 DPPH (Sigma-Aldrich) 라디칼 소거능은 Blois (1958)의 방 법을 변형하여 다음과 같이 실시하였다. 시료 $0.1 \mathrm{~mL}$ 에 $1.5 \times$ $10^{-4} \mathrm{M} \mathrm{DPPH}$ 용액을 가하여 실온 암소에서 $30 \mathrm{~min}$ 간 정치한 후 microplate reader를 이용하여 $517 \mathrm{~nm}$ 에서 흡광도를 측정 하였다. 모든 실험은 3 회 반복하여 평균값으로 계산하였다.

\section{6. 산양삼 분말을 첨가한 선식의 이화학적 성분 분석}

\section{1) 일반성분}

선식의 이화학적 성분은 $\mathrm{AOAC}$ (2005) 방법에 준하여 분석 하였다. 즉 수분함량은 건조기(HAHNVAPOR HS-2005V-N; Hanshin S\&T)를 이용하여 $105^{\circ} \mathrm{C}$ 에서 상압 가열 건조법(Jeong et al., 2008)으로 측정하였고, 조지방 정량은 Soxhlet 추출장치
(ROT-X-TRACT-S; Organomatio, USA)로 추출하여 측정하 였으며, 조회분은 $550{ }^{\circ} \mathrm{C}$ 에서 직접 회화법(Kim et al., 2006)으 로 분석하였으며, 조단백질 함량은 Auto-kjeldah법(Lee et al, 2002)으로 분석하였으며, 탄수화물 함량은 100에서 조단백질, 조지방, 조회분 및 수분함량을 모두 더한 값을 빼는 탄수화물 계 산법(Kong et al., 2008)으로 산출하였다.

2) 무기질

선식의 무기질 분석은 유도결합 플라즈마 측정법(Hwang et al., 2014)으로 칼슘(Ca), 인(P), 마그네슘( $\mathrm{Mg})$, 칼륨(K) 및 나 트륨 $(\mathrm{Na})$ 의 함량을 측정하였다.

\section{7. 통계처리}

실험결과는 SPSS statistics 21 (IBM, USA)을 이용하여 평균 과 표준편차를 구하였으며 각 실험군에 대해 분산 분석(analysis of variance, ANOVA)을 실시하였고 Duncan's multiple range test로 유의수준 $5 \%$ 에서 시료간의 유의차 검정을 실시하였다 $(p<0.05)$.

\section{Results and Discussion}

\section{Total polyphenol 함량}

1) 산양삼 분말의 total polyphenol 함량

총 폴리페놀은 항산화 활성에 대한 지표생리 활성물질로 수산 기를 가지는 방향족 화합물이며 항산화, 항균, 항암작용 등에 관 여하는 것으로 알려져 있다(Park et al,, 2016). 10년산 및 15 년산 산양삼 에탄올 추출물 시료의 총 폴리페놀 함량은 Table 2 에 제시된 바와 같다. 10 년산 산양삼 분말의 총 폴리페놀 함량은 $321.17 \pm 2.50 \mathrm{mg} \mathrm{TAE} / 100 \mathrm{~g}$ 이고, 15 년산 산양삼 분말의 총 폴리페놀 함량은 $334.86 \pm 9.50 \mathrm{mg} \mathrm{TAE} / 100 \mathrm{~g}$ 으로 10 년산 산 양삼 분말보다 유의적으로 높게 측정되었다. 이는 생장 년 수의 차이에서 나는 것으로 추측된다.

\section{2) 산양삼 분말 첨가 선식의 total polyphenol 함량}

산양삼 분말 첨가량 $(0,0.2 \%, 0.4 \%$ 및 $0.6 \%)$ 을 달리하여 제 조한 산양삼 첨가 선식 에탄올 추출물 시료의 총 폴리페놀 함량 은 Table 3 에 제시된 바와 같다. 산양삼 분말 첨가량이 $0 \%$ 인 대 조군의 총 폴리페놀 함량은 $163.54 \pm 2.45 \mathrm{mg} \mathrm{TAE} / 100 \mathrm{~g}$ 으 로 측정되었고, 10 년산 산양삼 $0.2,0.4,0.6 \%$ 첨가 선식의 총 폴 리페놀 함량은 각각 $188.43 \pm 1.35,197.48 \pm 2.63,205.92 \pm$ $5.20 \mathrm{mg} \mathrm{TAE} / 100 \mathrm{~g}$ 으로 측정되었다. 그리고 15 년산 산양삼 0.2 , $0.4,0.6 \%$ 첨가 선식의 총 폴리페놀 함량은 각각 $190.61 \pm 4.63$, $199.26 \pm 2.76,207.82 \pm 3.46 \mathrm{mg} \mathrm{TAE} / 100 \mathrm{~g}$ 으로 측정 되었다. 
Table 2. The total polyphenol content of 10 - and 15 -year-old cultivated wild ginseng

\begin{tabular}{lc}
\hline Sample $^{1)}$ & Total polyphenol content $\left[\mathrm{mg} \mathrm{TAE}^{21} / 100 \mathrm{~g}\right]$ \\
10yrWGP & $321.17 \pm 2.50^{\mathrm{b} 3 / 4)}$ \\
15yrWGP & $334.86 \pm 9.50^{\mathrm{a}}$ \\
\hline
\end{tabular}

${ }^{1)} 10 y$ rWGP, 10-year-old cultivated wild ginseng powder; 15yrWGP, 15-year-old cultivated wild ginseng powder.

${ }^{21} \mathrm{TAE}$, tannic acid equivalent.

${ }^{3)}$ Mean \pm standard deviation ( $\left.n=3\right)$.

${ }^{4)}$ Different superscripts within a column $(\mathrm{a}-\mathrm{b})$ indicate significant differences $(p<0.05)$.

Table 3. The total polyphenol content of Sunsik prepared with 10- and 15-year-old cultivated wild ginseng powder

\begin{tabular}{|c|c|}
\hline Groups & Total polyphenol content $\left[\mathrm{mg} \mathrm{TAE}^{2)} / 100 \mathrm{~g}\right.$. \\
\hline Control & $163.54 \pm 2.45^{\mathrm{d} 3 / 4)}$ \\
\hline 10yrWS0.2 & $188.43 \pm 1.35^{\mathrm{c}}$ \\
\hline 10yrWS0.4 & $197.48 \pm 2.63^{b}$ \\
\hline 10yrWSo.6 & $205.92 \pm 5.20^{\mathrm{ab}}$ \\
\hline 15yrWSO.2 & $190.61 \pm 4.63^{\mathrm{c}}$ \\
\hline 15yrWS0.4 & $199.26 \pm 2.76^{\mathrm{b}}$ \\
\hline 15yrWS0.6 & $207.82 \pm 3.46^{a}$ \\
\hline
\end{tabular}

${ }^{1)}$ Control, basic Sunsik consisting of several grains but not including cultivated wild ginseng powder; 10yrWS0.2, sample with 0.2\% 10yrWGP added to basic Sunsik; 10yrWS0.4, sample with 0.4\% 10yrWGP added to basic Sunsik; 10yrWS0.6, sample with 0.6\% 10yrWGP added to basic Sunsik; 15yrWS0.2, sample with 0.2\% 15yrWGP added to basic Sunsik; 15yrWS0.4, sample with 0.4\% 15yrWGP added to basic Sunsik; 15yrWS0.6, sample with 0.6\% 15yrWGP added to basic Sunsik; 10yrWGP, 10-year-old cultivated wild ginseng powder; 15yrWGP, 15-year-old cultivated wild ginseng powder.

${ }^{2)} \mathrm{TAE}$, tannic acid equivalent.

${ }^{3}$ Mean \pm standard deviation $(n=3)$.

${ }^{4)}$ Different superscripts within a column $(a-d)$ indicate significant differences $(p<0.05)$.

Table 4. The DPPH radical scavenging activity of 10- and 15-year-old cultivated wild ginseng powder

\begin{tabular}{lc}
\hline Sample $^{1)}$ & DPPH $^{2)}$ radical scavenging activity (\%) \\
10yrWGP & $72.24 \pm 1.19^{\text {b3/4) }}$ \\
15yrWGP & $80.17 \pm 1.64^{\mathrm{a}}$ \\
\hline
\end{tabular}

1) 10yrWGP, 10-year-old cultivated wild ginseng; 15yrWGP, 15-year-old cultivated wild ginseng.

${ }^{2} \mathrm{DPPH}, 1,1$-diphenyl-2-picrylhydrazyl.

${ }^{3}$ Mean \pm standard deviation $(n=3)$.

${ }^{4)}$ Different superscripts within a column $(a-b)$ indicate significant differences $(p<0.05)$.

10 년산 및 15 년산 산양삼 분말 첨가량이 증가할수록 산양삼 분말 첨가 선식의 총 폴리페놀 함량 측정값은 유의성 있게 증가 하였다 $(p<0.05)$. 이는 대조군보다 상대적으로 더 많은 폴리페놀 을 함유하고 있는 산양삼 첨가량의 증가에 따른 것으로 보여진 다.

\section{DPPH radical 소거능 측정}

\section{1) 산양삼 분말의 DPPH radical 소거능}

10 년산 및 15 년산 산양삼 에탄올 추출물 시료의 $\mathrm{DPPH}$ radical 소거능은 Table 4 에 제시된 바와 같다. 10년산, 15년 산 산양삼 분말의 $\mathrm{DPPH}$ radical 소거능은 각각 $72.24 \pm 1.19$, $80.17 \pm 1.64 \%$ 로, 15 년산 산양삼 분말의 DPPH radical 소거능
이 10 년산 산양삼 분말보다 상대적으로 높게 측정되었다. 산양 삼의 생장 년 수의 차이에 따라 총 폴리페놀 함량에 차이가 나는 것처럼 DPPH radical 소거능도 산양삼 생장 년 수에 따라 증가 하였다. 이는 Rhim et al. (2009)의 산양삼 추출물 농도가 증가 함에 따라 활성산소 소거능이 증가하였다는 결과와 같은 양상을 보였다.

2) 산양삼 분말을 첨가한 선식의 DPPH radical 소거능 산양삼 분말 첨가량 $(0,0.2 \%, 0.4 \%$ 및 $0.6 \%)$ 을 달리하여 제 조한 산양삼 첨가 선식 에탄올 추출물 시료의 DPPH radical 소 거능은 Table 5 에 제시된 바와 같다. DPPH radical 소거능 측 정결과, 대조군의 경우는 $34.46 \pm 0.24 \%$ 로 나타났고, 10 년산 산 
Table 5. The DPPH radical scavenging activity of Sunsik prepared with 10- and 15-year-old cultivated wild ginseng powder

\begin{tabular}{|c|c|}
\hline Groups $^{1)}$ & $\mathrm{DPPH}^{2)}$ radical scavenging activity (\%) \\
\hline Control & $34.46 \pm 0.24^{\mathrm{e} 34)}$ \\
\hline 10yrWS0.2 & $35.78 \pm 0.32^{\mathrm{cd}}$ \\
\hline 10yrWS0.4 & $36.64 \pm 0.27^{c}$ \\
\hline 10yrWS0.6 & $37.21 \pm 0.29^{b c}$ \\
\hline 15yrWS0.2 & $36.73 \pm 0.25^{c}$ \\
\hline 15yrWS0.4 & $37.74 \pm 0.19^{b}$ \\
\hline 15yrWS0.6 & $39.22 \pm 0.21^{\mathrm{a}}$ \\
\hline
\end{tabular}

${ }^{11}$ Control, basic Sunsik consisting of several grains but not including cultivated wild ginseng powder; 10yrWS0.2, sample with 0.2\% $10 y$ rWGP added to basic Sunsik; 10yrWS0.4, sample with 0.4\% 10yrWGP added to basic Sunsik; 10yrWS0.6, sample with 0.6\% 10yrWGP added to basic Sunsik; 15yrWS0.2, sample with 0.2\% 15yrWGP added to basic Sunsik; 15yrWS0.4, sample with 0.4\% 15yrWGP added to basic Sunsik; 15yrWS0.6, sample with 0.6\% 15yrWGP added to basic Sunsik; 10yrWGP, 10-year-old cultivated wild ginseng powder; 15yrWGP, 15-year-old cultivated wild ginseng powder.

${ }^{2)} \mathrm{DPPH}, 1,1$-diphenyl-2-picrylhydrazyl.

${ }^{3)}$ Mean \pm standard deviation $(n=3)$.

${ }^{4)}$ Different superscripts within a column $(a-e)$ indicate significant differences $(p<0.05)$.

Table 6. General compositions of basic Sunsik and Sunsik prepared with 15-year-old cultivated wild ginseng powder (Unit: g/100 g)

\begin{tabular}{lccccc}
\hline Variables & Moisture & Carbohydrate & Crude protein & Crude fat & Crude ash \\
Control $^{1)}$ & $6.10 \pm 0.05^{3)}$ & $80.50 \pm 0.13$ & $8.79 \pm 0.07$ & $2.40 \pm 0.12$ & $2.20 \pm 0.07$ \\
$15 y$ ySO $4^{2)}$ & $6.14 \pm 0.06$ & $80.79 \pm 0.12$ & $8.84 \pm 0.08$ & $2.40 \pm 0.15$ & $2.22 \pm 0.08$ \\
\hline
\end{tabular}

${ }^{1)}$ Control: basic Sunsik consisting of several grains but not including cultivated wild ginseng powder.

2) 15 yrWSO.4, sample with 0.4\% 15yrWGP added to basic Sunsik; 15yrWGP, 15-year-old cultivated wild ginseng powder.

${ }^{3)}$ Mean \pm standard deviation $(n=3)$.

Table 7. Mineral contents of basic Sunsik and Sunsik prepared with 15-year-old cultivated wild ginseng powder (Unit: $\mathrm{mg} / 100 \mathrm{~g}$ )

\begin{tabular}{|c|c|c|c|c|c|}
\hline Variables & $\mathrm{Ca}$ & $\mathrm{P}$ & $\mathrm{Na}$ & $\mathrm{K}$ & Mg \\
\hline Control $^{1)}$ & $56.03 \pm 0.21^{2)}$ & $220.96 \pm 5.44$ & $308.97 \pm 5.67$ & $505.59 \pm 7.72$ & $63.40 \pm 0.24$ \\
\hline $15 y r W S 0.4^{3)}$ & $56.91 \pm 0.49$ & $221.76 \pm 4.92$ & $309.83 \pm 4.73$ & $506.63 \pm 5.22$ & $64.16 \pm 0.21$ \\
\hline
\end{tabular}

${ }^{1)}$ Control, basic Sunsik consisting of several grains but not including cultivated wild ginseng powder.

${ }^{2)}$ Mean \pm standard deviation $(n=3)$.

3)15yrWS0.4, sample with 0.4\% 15yrWGP added to basic Sunsik; 15yrWGP, 15-year-old cultivated wild ginseng powder.

양삼 $0.2,0.4,0.6 \%$ 첨가 선식의 경우는 각각 $35.78 \pm 0.32$, $36.64 \pm 0.27,37.21 \pm 0.29 \%$ 로 나타났으며, 15 년산 산양삼 $0.2,0.4,0.6 \%$ 첨가 선식의 경우는 각각 $36.73 \pm 0.25,37.74$ $\pm 0.19,39.22 \pm 0.21 \%$ 로 나타났다. 산양삼 분말 첨가량이 증가 할수록 $\mathrm{DPPH}$ radical 소거능은 유의적으로 증가하여 $(p<0.05)$, 총 폴리페놀함량의 증가와 유사한 결과를 보였다. 이는 Jang et al. (2008)의 산양삼 비교연구에서 산양삼 추출물이 인삼에 비해 총 항산화능이 유의하게 높은 이유는 추출물 내에 존재하는 총 폴리페놀의 함량이 높기 때문이었다는 연구결과처럼 산양삼 분 말 첨가량이 증가 할수록 총 폴리페놀 함량이 증가함에 따른 것 으로 추측된다.

\section{3. 산양삼 분말을 첨가한 선식의 이화학적 성분}

1) 일반성분

대조군과의 관능평가 결과, 기호도가 가장 우수했던 15 년산 산양삼 분말 $0.4 \%$ 첨가 선식의 일반성분 함량을 분석한 결과 는 Table 6 에 제시된 바와 같다. 기본 선식은 $100 \mathrm{~g}$ 당 수분이 $6.10 \pm 0.05 \mathrm{~g}$, 탄수화물 $80.50 \pm 0.13 \mathrm{~g}$, 조단백질 $8.79 \pm 0.07$ $\mathrm{g}$, 조지방 $2.40 \pm 0.12 \mathrm{~g}$, 조회분 $2.20 \pm 0.07 \mathrm{~g}$ 으로 나타났다. 15 년산 산양삼 분말 $0.4 \%$ 첨가 선식의 일반성분 함량은 $100 \mathrm{~g}$ 당 수분이 $6.14 \pm 0.06 \mathrm{~g}$, 탄수화물 $80.79 \pm 0.12 \mathrm{~g}$, 조단백질 $8.84 \pm 0.08 \mathrm{~g}$, 조지방 $2.40 \pm 0.15 \mathrm{~g}$, 조회분 $2.22 \pm 0.08 \mathrm{~g}$ 이 었다. 이 같은 결과는 Lee et al. (2010)의 현미선식의 연구에 서 탄수화물 $81.0 \pm 5.2 \%$, 조단백질 $10.5 \pm 0.1 \%$, 조지방 $3.0 \pm$ 
$0.6 \%$, 조회분 $2.6 \pm 0.3 \%$ 와 비슷한 결과를 보였다. 대조군과 비 교하여 15 년산 산양삼 분말 $0.4 \%$ 첨가 선식의 탄수화물, 단백 질, 조지방, 조회분 함량 등의 일반 성분 함량은 변화를 보이지 않았다.

\section{2) 무기질}

대조군과의 관능평가 결과 기호도가 가장 우수했던 15 년산 산양삼 분말 $0.4 \%$ 첨가 선식의 무기질 함량을 분석한 결과는 Table 7에 제시된 바와 같다. 대조군은 $100 \mathrm{~g}$ 당 칼슘 $56.03 \pm$ $0.21 \mathrm{mg}$, 인 $220.96 \pm 5.44 \mathrm{mg}$, 나트륨 $308.97 \pm 5.67 \mathrm{mg}$, 칼 륨 $505.59 \pm 7.72 \mathrm{mg}$, 마그네슘 $63.40 \pm 0.24 \mathrm{mg}$ 으로 나타났 다. 15 년산 산양삼 분말 $0.4 \%$ 첨가 선식의 칼슘은 $56.91 \pm 0.49$ $\mathrm{mg}$, 인은 $221.76 \pm 4.92 \mathrm{mg}$, 나트륨은 $309.83 \pm 4.73 \mathrm{mg}$, 칼 륨은 $506.63 \pm 5.22 \mathrm{mg}$, 마그네슘은 $64.16 \pm 0.21 \mathrm{mg}$ 으로 두 군간의 차이는 나타나지 않았다. 산양삼 함유 선식이나 대조군 모두 야생당근 등 많은 과채류가 첨가되어 칼륨 함량이 높게 나 타난 것은 고혈압 등의 예방에 긍정적일 것으로 사료된다.

\section{Conclusion}

본 연구는 산양삼 분말을 첨가한 선식의 항산화 활성 및 이화 학적 성분을 분석하여 산양삼의 미용기능성 식품으로서의 가능 성을 탐색하고자 하였다. 그 결과 총 폴리페놀 함량은 산양삼의 첨가량이 많을수록 높게 나타났으며 DPPH radical 소거능도 산 양삼의 첨가량이 많은 시료에서 높게 나타났다. 또한 산양삼 15 년산이 첨가된 선식이 산양삼 10 년산이 첨가된 선식보다 폴리페 놀 함량이 많았으며, DPPH radical 소거능 또한 높았다. 산양 삼 분말 $0.4 \%$ 첨가한 선식의 단백질, 조지방, 조회분 등의 일반 성분 및 무기질 함량은 대조군과 차이가 없었으나, 무기질 성분 인 칼륨이 많이 함유되어 있어서 고혈압 예방에도 긍정적일 것으 로 판단된다. 결론적으로 산양삼 첨가 선식은 총 폴리페놀 함량 이 많고 $\mathrm{DPPH}$ radical 소거능이 높아 향후 항산화 미용기능성 식품으로서의 활용 가능성 뿐만 아니라 식사대용식, 환자식, 유 아식 등으로 응용되는 기초자료로 활용될 수 있을 것으로 사료된 다. 향후 산양삼을 이용한 미용기능성 식품에 관한 다양한 연구 가 이루어지길 기대하는 바이다.

This work is part of Sei-Woo Lee's M.S. thesis at Kyonggi University, Seoul, Korea.

\section{References}

AOAC. Official methods of analysis (18th ed.). Association of Officiating Analytical Chemists, Washington DC, pp112113, 2005.

Blois MS. Antioxidant determinations by the use of a stable free radical. Nature, 181: 1199-1200, 1958.

Choi YE, Kim YS, Yi MJ, Park WG, Yi JS, Chun SR, Han SS, Lee SJ. Physiological and chemical characteristics of field-and mountain-cultivated ginseng roots. Journal of Plant Biology, 50: 198-205, 2007.

Chung SS, Han YS. Consumer's recognition, nutrient composition, and safety evaluation of commercial Sunsik and Saengsik. Journal of the Korean Society of Dietary Culture, 18: 235-243, 2003.

Folin O, Denis W. On phosphotungstic-phosphomolybdic compounds as color reagents. Journal of Biological Chemistry, 12: 239-243, 1912.

Hwang J, Bae N, Oh M, Kim S, Shim YS, Kim SN, Choi Y, Nam J. Method validation for 9 types of minerals in infant and adult nutritional formulas using inductively coupled plasma optical emission spectrometry. Food Engineering Progress, 18: 256-260, 2014.

Jang HY, Park HS, Kwon KR, Rhim TJ. A study on the comparison of antioxidant effects among wild ginseng, cultivated wild ginseng, and cultivated ginseng extracts. Journal of Pharmacopuncture, 11: 67-78, 2008.

Jang YA. Efficacy of a cosmetic material from complex extracts of Vaccinium spp., Phellinus linteus, Castanea crenata, and Cimicifuga heracleifolia. Asian Journal of Beauty and Cosmetology, 15: 281-290, 2017.

Jeong KY, Kim MY, Chun SS. Quality characteristics of Sulgidduk with concentrated sweet pumpkin powder. Korean Journal of Food and Cookery Science, 24: 849855, 2008.

Jung EY, Hwang SK. Health literacy and health behavior compliance in patients with coronary artery disease. Korean Journal of Adult Nursing, 3: 251-261, 2015.

Kang MJ, Joung HJ, Lim JH, Lee YS, Song YJ. Secular trend in dietary patterns in a Korean adult population, using the 1998, 2001, and 2005 Korean national health and nutrition examination survey. Journal of Nutrition and Health, 44: 152-161, 2011. 
Kang SY, Kim MK, Ryu HW. Influence of the concentration of Lavender oil on brain activity. Asian Journal of Beauty and Cosmetology, 11: 1099-1107, 2013.

Kim AJ, Yuh CS, Bang IS, Woo KJ. Study on preparation and quality of jelly using mulberry leaf powder. Korean Journal of Food and Cookery Science, 22: 56-61, 2006.

Kim EL, Kim CS, Lee HY, Lee HR, Kim EY, Yoon MC, Shin SS. Mountain cultivated ginseng water boiled extract decreases blood glucose level and improves lipid metabolism in male $\mathrm{db} / \mathrm{db}$ mice. The Korea Journal of Herbology, 27: 69-75, 2012.

Kim JH, Park PS, Kim JK. Manufacture of nutritionally balanced "Sunsik" for the moderns: its quality characteristics. Korean Journal of Food Preservation, 12: 123-129, 2005.

Kim NI. Role of vitamines and minerals on skin care and beauty. Food Science and Industry, 38: 16-25, 2005.

Kim SJ, Choi HS, Cho HI, Jin YW, Lee EK, Ahn JY, Lee SM. Protective effect of wild ginseng cambial meristematic cells on D-galactosamine-induced hepatotoxicity in rats. Journal of Ginseng Research, 39: 376-383, 2015.

Kim SJ, Shin SS, Seo BI, Jee SY. Effect of mountain grown ginseng radix, mountain cultivated ginseng radix, and cultivated ginseng radix on apoptosis of $\mathrm{HL}-60$ cells. The Korea Journal of Herbology, 19: 41, 2004.

Kim YJ, Jeon JN, Jang MG, Oh JY, Kwon WS, Jung SK, Yang DC. Ginsenoside profiles and related gene expression during foliation in Panax ginseng Meyer. Journal of Ginseng Research, 38: 66-72, 2014.

Kong BM, Park MJ, Min JW, Kim HB, Kim SH, Kim SY, Yang DC. Physico-chemical characteristics of white, fermented and red ginseng extracts. Journal of Ginseng Research, 32: 238-243, 2008.

Kwon SJ, Chung DK. The immune-enhancing effect of mountain gown ginseng, mountain cultivated ginseng, and Panax ginseng. Journal of Oriental Neuropsychiatry,
15: 89-101, 2004.

Lee BY, O J, Kim MH, Jang KH, Lee JC, Surh J. Influences of roasted or non-roasted brown rice addition on the nutritional and sensory properties and oxidative stability of Sunsik, Korean heated cereal powder. Korean Journal of Food and Cookery Science, 26: 872-886, 2010.

Lee DG, Lee AY, Kim KT, Cho EJ, Lee S. Novel dammaranetype triterpene saponins from Panax ginseng root. Chemical and Pharmaceutical Bulletin, 63: 927-934, 2015.

Lee SM, Jeon IG, Lee JY. Effects of digestible protein and lipid levels in practical diets on growth, protein utilization and body composition of juvenile rockfish (Sebastes schlegeli). Aquaculture, 211: 227-239, 2002.

Rhim TJ, Jeong HS, Kim YJ, Kim DY, Han YJ, Kwon HY, Kwon KR. A study on the comparison of antioxidant effects among cultivated ginseng, and cultivated wild ginseng extracts: using the measurement of superoxide and hydroxy radical scavenging activities. Journal of Pharmacopuncture, 12: 7-12, 2009.

Park JY, Choi P, Kim HK, Kang KS, Ham J. Increase in apoptotic effect of Panax ginseng by microwave processing in human prostate cancer cells: in vitro and in vivo studies. Journal of Ginseng Research, 40: 62-67, 2016.

Shin SS, Kim KC, Choi YH, Lee YT, Eom HS, Kim CS. Critic standardization and objectivity of mountain grown ginseng. Journal of Dong-Eui Oriental Medicine, 5: 107114, 2001.

Yeom MH, Lee JY, Kim JS, Park CW, Kim DH, Kim HK. The anti-aging effects of Korean ginseng berry in the skin. Korean Journal of Pharmacognosy, 41: 26-30, 2010.

Yun SN, Moon SJ, Ko SK, Im BO, Chung SH. Wild ginseng prevents the onset of high-fat diet induced hyperglycemia and obesity in ICR mice. Archives of Pharmacal Research, 27: 790-796, 2004. 


\section{국문초록}

\section{산양삼 분말을 첨가한 선식의 미용기능성 식품으로서의 응용 가능성}

이세우 ${ }^{1}$ 최형일 ${ }^{2}$, 김애정*, 한정순 ${ }^{3 *}$

${ }^{1}$ 경기대학교 대체의학과, 서울, 한국

${ }^{2}$ 경기대학교 대체의학대학원 식품치료전공, 서울, 한국

${ }^{3}$ 고려대학교 생활과학연구소, 서울, 한국

목적: 본 연구에서는 산양삼 분말을 첨가한 선식의 항산화 활성을 확인하여 미용기능성 식품으로서의 응용 가능성을 검증하고자 하였다. 방법: 산양삼 분말이 함유된 선식을 $70 \%$ 에탄올로 추출하여 1,1-diphenyl-2-picrylhydrazyl (DPPH) radical 소거능으로 항산화 활성을 측정하였다. 이화학적 분석은 $\mathrm{AOAC}$ 방법에 준하여 수분, 조지방, 조회분, 조단백질 함량을 측정하였으며 무기질 분 석은 유도결합 플라즈마 측정법으로 칼슘, 마그네슘, 칼륨, 나트륨의 함량을 분석하였다. 실험결과는 SPSS statistics 21 을 이용하 여 평균과 표준편차를 구하였으며 각 실험군에 대해 분산 분석(ANOVA)을 실시하였고, Duncan's multiple range test로 각 시료의 평균차이에 대한 사후 검정은 유의수준 $5 \%$ 에서 실시하였다. 결과: 15 년산 산양삼 분말 $0.6 \%$ 가 첨가된 선식의 총 폴리페놀 함량이 많았으며, DPPH radical 소거능도 우수하였다. 15 년산 산양삼 분말 $0.4 \%$ 가 첨가된 선식의 일반 성분과 무기질 성분을 분석한 결과, 조단백질, 조회분 등은 대조군과 차이가 없었다. 결론: 산양삼 분말이 첨가된 선식은 항산화 활성이 우수하므로, 체내 항산화 기능 을 증진시킬 수 있는 미용기능성 식품으로서의 응용 가능성이 높은 것으로 판단된다.

핵심어: 선식, 산양삼, 폴리페놀, 항산화, 미용기능성 식품

\section{참고문헌}

강승연, 김민경, 류희욱. 라벤다 오일의 농도변화가 뇌 활성에 미치는 영향. 아시안뷰티화장품학술지, 11: 1099-1107, 2013.

권순주, 정대규. 山莩、長腦苶、人茓의 免疫增强효과 비교연구. 동의신경정신과 학회지, 15: 89-101, 2004.

김낙인. 피부건강 및 미용에 있어 비타민과 미네랄의 역할. 식품과학과 산업, 38: 16-25, 2005.

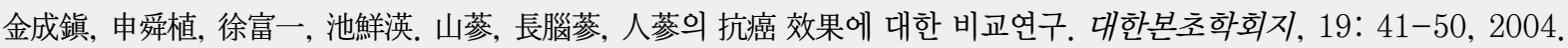

김응래, 김창식, 이희영, 이혜림, 김응렬, 윤미정, 신순식. 山養山蔘 열수추출물이 $d b / d b$ 마우스 당뇨모델에서 혈중 지질 대사와 혈당에 미치는 영향. 대한본초학회지, 27: 69-75, 2012.

김애정, 여정숙, 방인수, 우경자. 뽕잎을 이용한 젤리제조 및 품질특성에 관한 연구. 한국식품조리과학회지, 22: 56-61, 2006.

김준한, 박필숙, 김종국. 현대인을 위한 영양균형선식의 제조와 품질. 한국식품저장유통학회지, 12: 123-129, 2005. 신순식, 김경철, 최영현, 이용태, 엄현섭, 김창식. 산삼 감정 기준의 객관성. 동의한의연, 5: 107-114, 2001. 염명훈, 이진영, 김지성, 박찬웅, 김덕희, 김한곤. 인삼열매의 피부노화 억제 효과. 생약학회지, 41: $26-30,2010$. 이병용, 오지환, 김미현, 장기효, 이재철, 서정희. 현미의 볶음 처리 유무와 첨가량이 선식의 영양적 관능적 특성 및 산화안 정성에 미치는 영향. 한국식품조리과학회지, 26: 872-886, 2010.

장영아. 블루베리, 상황, 율피, 승마 복합추출물의 화장품 소재로서의 효능. 아시안뷰티화장품학술지, 15: 281-290, 2017.

정기영, 김문용, 전순실. 농축단호박 분말을 대체한 설기떡의 품질 특성. 한국식품조리과학회지, 24: 849-855, 2008. 정선순, 한영실. 시판 선식.생식 제품에 대한 소비자 인식조사와 영양성분 및 위생안전성 분석에 관한 연구. 한국식생활문 화학회지, 18: 235-243, 2003. 
정은영, 황선경. 관상동맥질환자의 건강정보이해능력과 건강행위이행. 성인간호학회지, 27: 251-261, 2015.

황진봉, 남궁배, 오미라, 김소영, 심유신, 김세나, 최용미, 남진식. Inductively Coupled Plasma Optical Emission Spectrometry를 이용한 조제분유의 9종 무기질 분석법의 유효성 검증. 산업식품공학, 18: 256-260, 2014. 


\section{中文摘要}

\section{含有野山参粉的禅食（Sunsik）作为美容功能性食品的适用性}

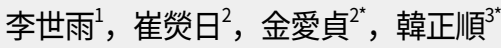

1京畿大学代替医疗大学, 首尔, 韩国

2京畿大学代替医疗大学院, 食品治疗学科, 首尔, 韩国

3高丽大学生活科学研究所, 首尔, 韩国

目的: 确认添加栽培野山参粉的禅食的抗氧化活性, 鉴定美容健康食品的应用可行性。方法: 含有栽培野山参 粉的禅食用70\%乙醇提取，并利用1,1-diphenyl-2-picrylhydrazyl（DPPH）自由基消除法测定抗氧化活性。按 照AOAC方法, 通过物理化学分析测定水分, 粗脂肪, 粗灰分, 粗蛋白。钙、磷、镁、钾和钠的含量也通过电 感耦合等离子体方法测量。使用 SPSS statistics 21 统计数据计算平均值和标准偏差, 对每个测试组进行分散分 析 (ANOVA)，并且在 $5 \%$ 的显着性水平下进行Duncan的多范围测试。结果：含有 $0.6 \% 15$ 年栽培野山参粉禅食 （15yrWS0.6）的总多酚含量被确定为是所有样品中最高的，而15yrWS0.6的DPPH自由基清除活性也是很优秀。 测定含有 $0.4 \% 15$ 年栽培野山参粉禅食的一般成分和矿物质成分分析结果 : 粗灰分, 粗蛋白含量与对照群相比无 差异。结论: 含有栽培野山参粉的禅食的抗氧化性优秀, 因此, 作为一种增强体内抗氧化作用的美容健康食品充 分具有应用可行性。

关键词: 禅食, 栽培野山参粉, 多酚, 抗氧化，美容功能性食品 